\title{
Management of immediate postcesarean section hemorrhage
}

\author{
ROBERT A. SALK, CPT, MC, USA \\ ENRIQUE HERNANDEZ, MAJ, MC, USA \\ KUNIO MIYAZAWA, COL, MC, USA
}

From Jan 1, 1982, to Dec 31, $1985,33(1.3 \%)$ of 2,545 women undergoing cesarean section experienced an immediate estimated blood loss $>1,000 \mathrm{~mL}$. In all cases, the etiology was uterine atony. Medical management was unsuccessful in $20(60.6 \%)$ cases, and hysterectomy was necessary in ten. Conservative surgical management (hypogastric or uterine artery ligation or both) was used in 18 cases and was successful in ten $(55.6 \%)$. Patients who responded to medical management had a mean estimated blood loss of $1,469 \mathrm{~mL}$, compared to a loss of $2,120 \mathrm{~mL}$, for those responding to ligation and a loss of 3,240 $\mathrm{mL}$ for those requiring hysterectomy $(P<0.001)$. Hysterectomy is the definitive procedure for the hemodynamically unstable patient with intractable obstetric hemorrhage if rapid bilateral uterine artery ligation fails. Hypogastric or uterine artery ligation is recommended for the hemodynamically stable patient who is desirous of future childbearing.

Postpartum hemorrhage occurs in approximately $5 \%$ of all deliveries; uterine atony and birth canal lacerations are the most frequent primary causes..$^{1,2}$ Conventional treatment of uterine atony traditionally has consisted of fluid resuscitation, intravenous oxytocin, intravenous or intramuscular methylergonovine maleate, and uterine massage. Recently, 15-methyl-prostagladin F2 alpha was reported ${ }^{1}$ to be successful in treating $86 \%$ of women with severe postpartum hemorrhage that was unresponsive to conventional therapy. When medical therapy fails, uterine or hypogastric artery ligation, or hysterectomy, or both, becomes necessary.

Predisposing causes for uterine atony include high parity, overdistended uterus, abrupt or prolonged labor, general anesthesia, magnesium sulfate, and chorioamnionitis..$^{1,2}$ In Hayashi and associates ${ }^{1}$ study, most women with intractable uter- ine atony had undergone operative delivery, with $49 \%$ having had a cesarean section.

The present study was limited to the management of women with intractable hemorrhage after cesarean section. Emphasis was placed on the effectiveness of bilateral hypogastric or uterine artery ligation.

\section{Methods and materials}

The hospital charts of women who had experienced hemorrhage at the time of cesarean section at Tripler Army Medical Center between Jan 1, 1982, and Dec 31, 1985, were reviewed. Hemorrhage was defined as an estimated blood loss $>1,000 \mathrm{~mL}$. During this time period, there were 13,781 deliveries, $2,545(18.5 \%)$ of which were by cesarean section. All cases were managed by resident physicians under attending staff supervision.

The following data were analyzed: age, parity, fetal weight, estimated blood loss, etiology of hemorrhage, medical management, surgical management, and total amount and duration of oxytocin use during labor. Statistical analysis was performed using two-tailed Student's t-test, one-way analysis of variance, or chi-square test when appropriate.

\section{Results}

During the study period, $33(1.3 \%)$ of the 2,545 cesarean section patients experienced obstetric hemorrhage $>1,000 \mathrm{~mL}$. All 33 women had been in labor, and uterine atony was thought to be responsible for the hemorrhage in all cases. All were treated with intravenous oxytocin and intramuscular methylergonovine maleate. In 18 cases, $1 \mathrm{mg}$ of intramyometrial natural prostaglandin $\mathrm{F} 2$ alpha also was used. In $20(60.6 \%)$ women, medical treatment was unsuccessful and surgery was performed (Table 1). In all cases, the decision to operate was made by the attending staff obstetrician.

The patients' mean \pm SD age was $24 \pm 4.5$ years. There were $27(1.8 \%)$ nulliparous women. The mean \pm SD fetal weight was $3,527 \pm 752 \mathrm{~g}$. Eighteen $(54.5 \%)$ women had received oxytocin to 
induce or augment their labor. The mean \pm SD duration of oxytocin administration during labor was $15.7 \pm 10.6$ hours, and the mean \pm SD total amount of oxytocin infused was $7,113 \pm 9,384 \mathrm{mU}$.

No woman was diagnosed as having chorioamnionitis, but six $(18.2 \%)$ patients developed postpartum endomyometritis. In two multiparous, hemodynamically unstable women with blood loss in excess of $3,000 \mathrm{~mL}$, immediate hysterectomy was performed. In one instance, hysterectomy was performed after a unilateral hypogastric artery ligation failed to control the bleeding. Hysterectomy was necessary in seven $(46.7 \%)$ of the 15 cases with bilateral arterial ligations. Therefore, ten $(30.3 \%)$ of the 33 women with immediate postcesarean section hemorrhage required hysterectomy.

The patient's mean \pm SD age, parity, fetal weight, estimated blood loss, and amount and duration of oxytocin administration during labor for the three modalities of management are listed in Table 2. The means of the estimated blood loss were statistically significantly different; they were higher in women requiring surgical management, and higher still in those undergoing hysterectomy. The mean total amount of oxytocin administered during labor to women undergoing hysterectomy was $15,982 \mathrm{mU}$, which differs significantly from the mean of $4,809 \mathrm{mU}$ infused to the 23 women who did not require hysterectomy $(P=.02)$. Although patients with failed medical therapy delivered larger infants (mean $\pm \mathrm{SD}, 3,709 \pm 676 \mathrm{~g}$ ) than those for whom medical treatment was successful (mean $\pm \mathrm{SD}, 3,247 \pm 803 \mathrm{~g}$ ), this difference did not reach statistical significance $(P=.08)$.

\section{Discussion}

Several factors, including dysfunctional labor and the use of oxytocin, have been associated with uterine atony. ${ }^{2}$ Labor induction or augmentation with oxytocin occurred in $54.5 \%$ of the women in the present series. Patients who required hysterectomy received significantly more intrapartum oxytocin than those who responded to medical or conservative surgical management. A primary blunted response of the myometrium to oxytocin might have been responsible for the need to induce or augment labor, the uterine atony, and the failure to respond to conservative therapy. An alternate explanation is that the large amounts of oxytocin administered caused down regulations of its receptors, thus precluding further myometrial response.

Most cases of postpartum hemorrhage secondary to uterine atony respond to conventional therapy (intravenous oxytocin, intravenous or intramuscular methylergonovine maleate, and uterine massage). ${ }^{1}$ Natural prostaglandin F2 alpha is metabo-

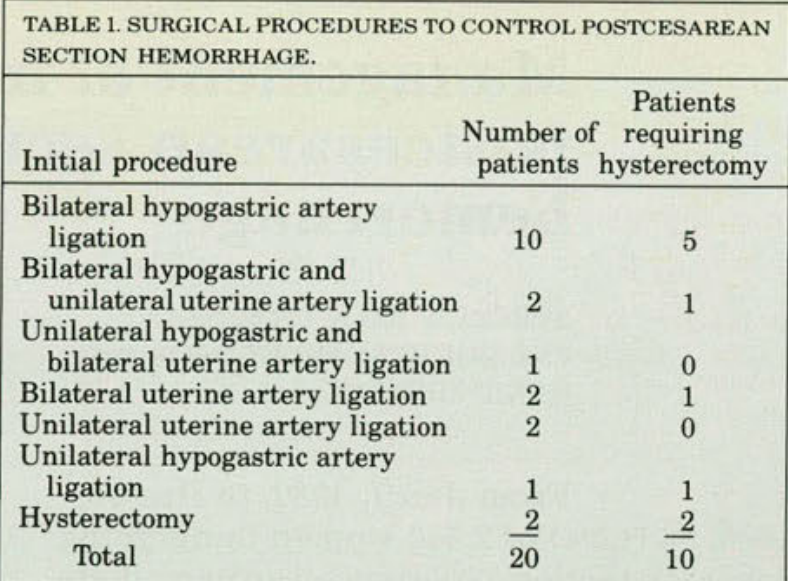

lized rapidly in the circulation. It has been found to be ineffective in the management of postpartum hemorrhage when administered intravenously or intramuscularly, but it is effective when injected directly into the myometrium. ${ }^{3,4} \mathrm{~A}$ prostaglandin analogue, 15-methyl-prostaglandin F2 alpha, is highly effective when administered intramuscularly in treating severe postpartum hemorrhage secondary to uterine atony. ${ }^{1}$ In the present study, only $39.4 \%$ of women responded to medical therapy, which included intramyometrial prostaglandin F2 alpha. We can only speculate that a higher success rate might have been achieved if 15 -methylprostaglandin F2 alpha had been used.

If medical management fails to control postpartum hemorrhage, hypogastric, ovarian, or uterine artery ligation or hysterectomy is required. In approximately $57 \%$ of women with intractable postpartum bleeding, conservative surgical procedures are unsuccessful. ${ }^{1,5,6}$ In the present study, bilateral hypogastric artery ligation failed to control bleeding in 6 of 12 patients. Clark and associates ${ }^{5}$ found that hypogastric artery ligation was ineffective in $60 \%$ of women with uterine atony that was unresponsive to medical therapy. Hysterectomy has been performed to control hemorrhage in approximately $1 \%$ of all women delivered by cesarean section. ${ }^{7}$ In the present series, hysterectomy was performed for hemostasis in $10(0.39 \%)$ of the 2,545 cesarean section patients during the study period.

Necrosis of the pelvic organs after hypogastric artery ligation rarely occurs. ${ }^{6}$ Because of a network of anastomosing collateral vessels, adequate blood flow to the pelvic organs after such ligation usually is maintained. The main collateral blood supply comes from the middle sacral, lumbar, and superior hemorrhoidal vessels. To avoid anastomotic reversal of blood flow through the iliolumbar-lumbar and lateral sacral-middle sacral anastomoses, 
TABLE 2 MEAN \pm SD OF THE FACTORS STUDIED FOR PATIENTS RESPONDING TO MEDICAL MANAGEMENT OR CONSERVATIVE SURGERY AND FOR PATIENTS REQUIRING HYSTERECTOMY.

\begin{tabular}{|c|c|c|c|c|}
\hline Factor & $\begin{array}{l}\text { Medical } \\
\text { therapy }\end{array}$ & $\begin{array}{c}\text { Conservative } \\
\text { surgery }\end{array}$ & Hysterectomy & $P$ value \\
\hline Patients (n) & 13 & 10 & 10 & \\
\hline Age $(y r)$ & $25 \pm 4$ & $23 \pm 5$ & $25 \pm 5$ & 0.62 \\
\hline Nulliparity $(\%)$ & 85 & 75 & 90 & 0.48 \\
\hline Fetal weight $(\mathrm{g})$ & $3,247 \pm 803$ & $3,943 \pm 306$ & $3,475 \pm 866$ & 0.08 \\
\hline Estimated blood loss (mL) & $1,469 \pm 545$ & $2,120 \pm 691$ & $3,240 \pm 1018$ & $<0.001$ \\
\hline Patients receiving oxytocin during labor (n) & 6 & 7 & 5 & \\
\hline Duration of oxytocin administration (hr) & $14.6 \pm 10$ & $10.4 \pm 4.4$ & $24.4 \pm 12.9$ & 0.06 \\
\hline Total amount of oxytocin (mU) & $5,565 \pm 6,200$ & $4,161 \pm 3,636$ & $15,982 \pm 14,189$ & 0.07 \\
\hline
\end{tabular}

ligation must be performed distally to the origin of the posterior division. Bilateral hypogastric artery ligation causes a $24 \%$ decrease in mean pressure within the hypogastric artery distal to the ligature and a $48 \%$ decrease in blood flow; the most significant change is that of an $85 \%$ decrease in pulse pressure. ${ }^{8}$ Thus, the hemodynamics of the distal arterial system more closely resemble those of a venous system, in which hemostasis by simple clot formation can occur.

A rapid and simple technique, ligation of the uterine artery as it ascends along the lateral margin of the uterus, with or without hypogastric artery ligation, was performed in seven cases in our series. Hysterectomy was performed in only $2(28.6 \%)$ of these patients. This technique and ovarian artery ligation have been advocated ${ }^{7,9,10}$ in the conservative surgical management of obstetric hemorrhage. No significant complications have been identified on long-term follow up..$^{9,11}$ Recanalization of the uterine arteries has been observed to occur in all cases. ${ }^{11}$ In our institution, the attending obstetricians prefer ligation of the uterine artery over the ovarian. No ovarian artery ligation was performed in the present series.

\section{Conclusions}

This study, along with others, ${ }^{1,5,6}$ has demonstrated that conservative surgical control of intractable postpartum hemorrhage is possible in about half of cases. These procedures should always be attempted in the hemodynamically stable patient who desires future childbearing. In the hemodynamically unstable patient, a rapid bilateral uterine artery ligation may be performed. If it fails to control the bleeding, subtotal hysterectomy is the fastest, safest, and most effective way to achieve hemostasis.

1. Hayashi RH, Castillo MS, Noah ML: Management of severe postpartum hemorrhage with a prostaglandin F2 alpha analogue. Obstet Gynecol 1984;63:806-808.

2. Pritchard, JA, MacDonald PC, Gant, NF (eds): Williams Obstetrics, ed 17. East Norwalk, Conn, Appleton-Century-Crofts, 1984, pp 707-718. 3. Takagi S, Yoshida T, Togo, Y, et al: The effects of intramyometrial injection of prostaglandin F2 alpha on severe postpartum hemorrhage. Prostaglandins 1976;12:565-579.

4. Jacobs MM, Arias, F: Intramyometrial prostaglandin F2 alpha in the treatment of severe postpartum hemorrhage. Obstet Gynecol 1980;55:665666.

5. Clark SL, Phelan JP, Yeh S-Y, et al: Hypogastric artery ligation for obstetric hemorrhage. Obstet Gynecol 1985;66:353-356.

6. Evans S, McShane P: The efficacy of internal iliac artery ligation in obstetric hemorrhage. Surg Gynecol Obstet 1985;160:250-253.

7. O'Leary JA: Stop Ob hemorrhage with uterine artery ligation. Comtemp Obstet Gynecol 1986;28(June):13-16.

8. Burchell RC: Internal iliac artery ligation: Hemodynamics. Obstet Gynecol 1964;24:737-739.

9. O'Leary JL, O'Leary JA: Uterine artery ligation for control of postcesarean section hemorrhage. Obstet Gynecol 1974;43:849-853.

10. Cruikshank SH, Stoelk EM: Surgical control of pelvic hemorrhage: Method of bilateral ovarian artery ligation. Am J Obstet Gynecol 1983;147:724-725.

11. O'Leary JA: Pregnancy following uterine artery ligation. Obstet Gynecol 1980;55:112-113.

The opinions and assertions contained herein are the private views of the authors and are not to be construed as official or as reflecting the Department of the Army or the Department of Defense.

From the Department of Obstetrics and Gynecology, Tripler Army Medical Center, Honolulu, Hawaii.

Reprint requests to Dr Hernandez, Medical College of Pennsylvania, 3300 Henry Ave, Philadelphia, 19129. 


\section{American Osteopathic Association \\ Continuing Medical Education}

\section{CERTIFICATION OF HOME STUDY}

This is to certify that I,

activity for AOA CME credits.

Please print

completed the following

Type of activity (such as reading or listening)

Name of journal(s) or audio-tape and date(s) of issue(s):

(One-half CREDIT may be granted for each issue or tape)

MAIL TO: AOA Division of CME, 142 East Ontario Street, Chicago, Illinois 60611

KEEP A DUPLICATE FOR YOUR RECORDS!

The Home Study form is intended to document individual reading of recognized scientific journals, listening to approved audio-tapes, and other approved home study courses and programs under the criteria described for Category 2-B.

Only one type of home study, such as reading, should be indicated on a single form, though multiple issues of scientific journals may be listed.

This form should not be used, however, when CME quiz cards for the AOA Journal are submitted separately.

\begin{tabular}{|l|}
\hline FOR OFFICE USE ONLY \\
\hline Date $\_$Credits \\
Program \# \\
Doctor \# \\
Doctor's Name
\end{tabular}

Please refer to the revised CME GUIDE for additional information. 


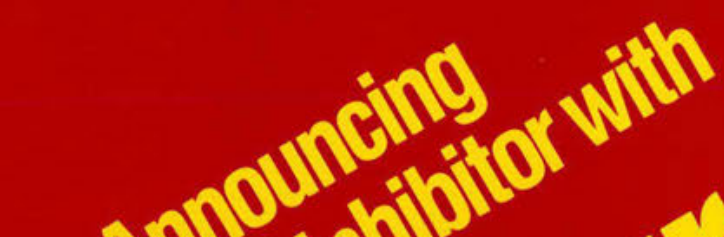

(1)

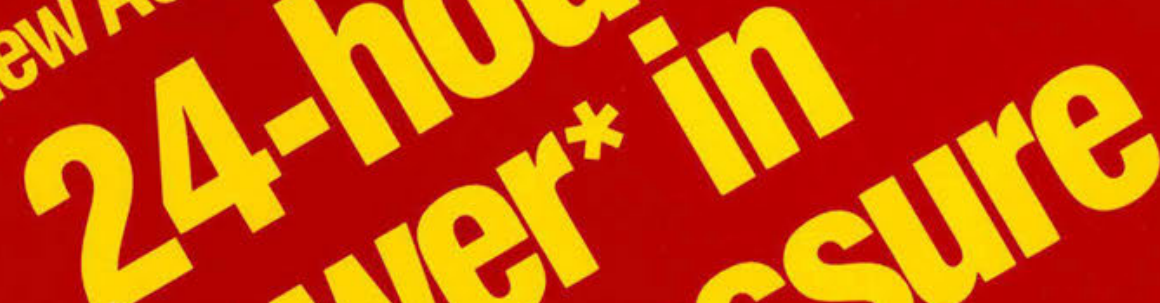

1)<smiles>c1cc2ccc1-2</smiles>

(1) 1100

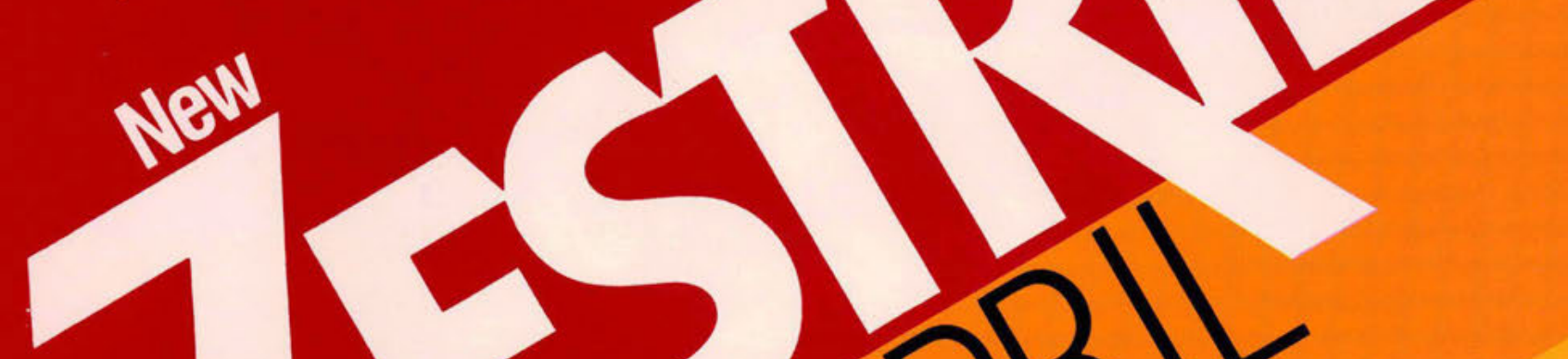

The antihypertensive effect may diminish at the end of the dosing interval.

Please see last page of this advertisement for brief summary of prescribing information. 


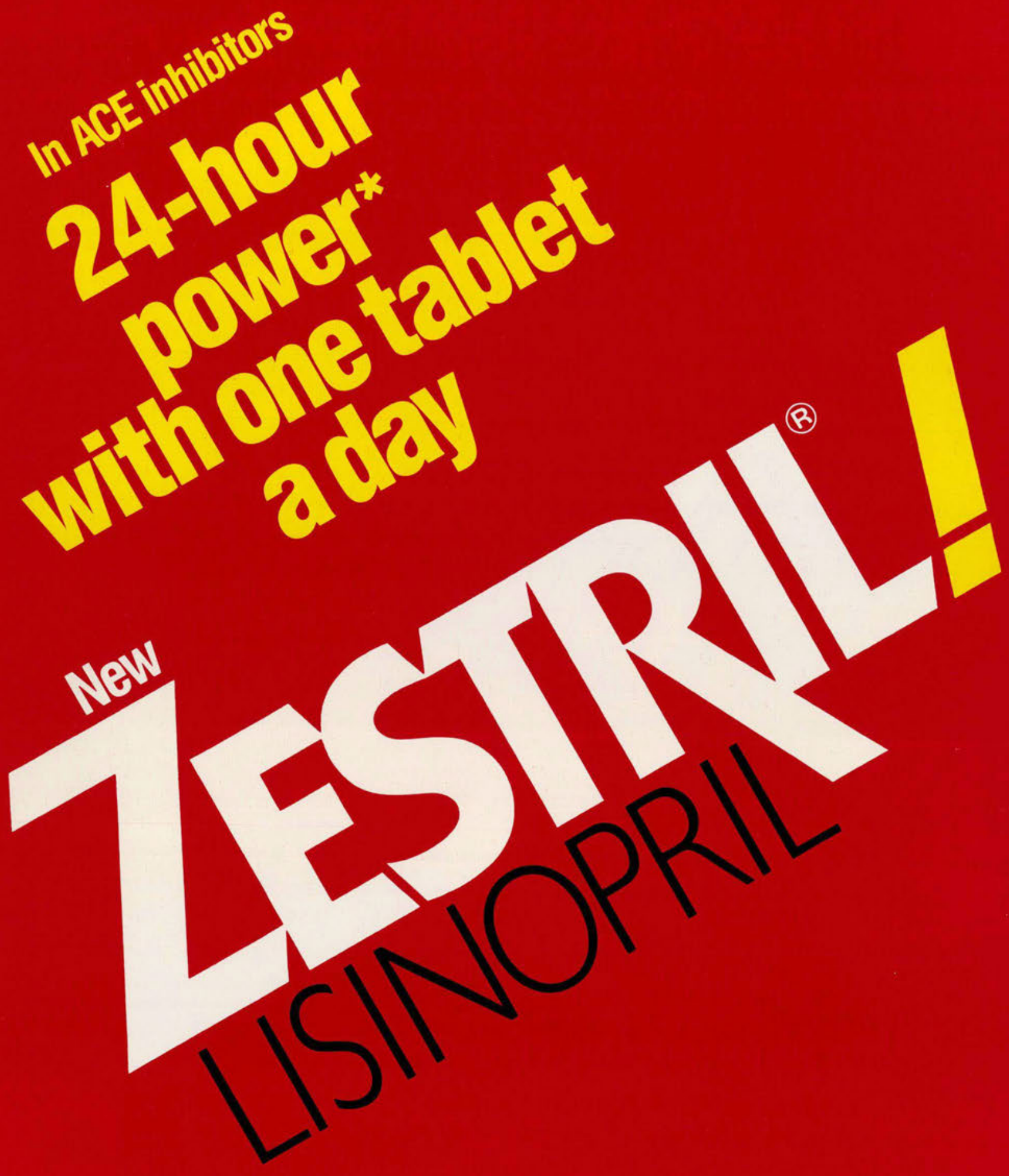

\section{Zestril: The long-acting ACE inhibitor}

Zestril achieves 24-hour blood pressure control with a half-life of 12 hours.' Angiotensin converting enzyme (ACE) inhibition t is long lasting with Zestrilsustained 24 hours after a single dose. ${ }^{2-4}$ The clinical significance of pharmacodynamic differences among ACE inhibitors in hypertensive patients has not been determined. 


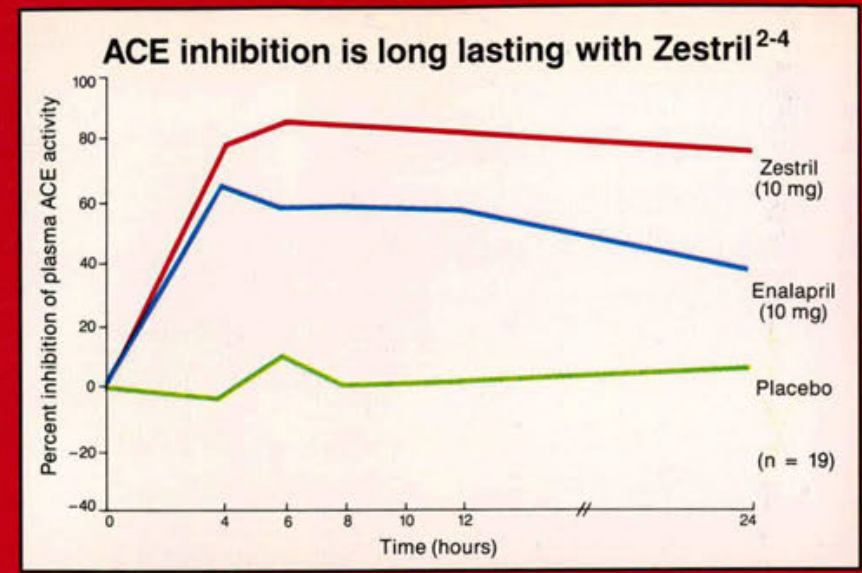

†In pharmacodynamic studies (utilizing $10 \mathrm{mg}$ of enalapril and lisinopril), ACE inhibition was significantly correlated to plasma renin activity and fall in diastolic blood pressure in normal volunteers.

- adapted from Ajayi et al, p $424^{2}$

\section{Zestril: Hypertensive patients start and stay at one tablet a day}

A single tablet of Zestril reduces blood pressure for 24 hours ${ }^{1}$ - unlike other ACE inhibitors, which may have to be increased to b.i.d. ${ }^{5}$ or t.i.d. ${ }^{6}$ dosing in some patients. The predictable once-daily dosage of Zestril enhances patient compliance and cost-effectiveness.

\section{Zestril: 24-hour blood pressure control that's easy to live with}

Zestril shares the low incidence of side effects characteristic of ACE inhibitors. Additionally, rash or taste disturbance are rarely seen with Zestril. What's more, Zestril is not metabolized by the liver. It is absorbed as the active drug and does not require bioactivation ${ }^{7}-$ as needed with prodrugs such as enalapril. ${ }^{\ddagger 5,7}$ Absorption of Zestril is unaffected by food. ${ }^{8}$

Evaluation of the hypertensive patient should always include assessment of renal function. (See Dosage and Administration.) Angioedema has been reported with ACE inhibitors, including Zestril. (See Warnings.)

1988 ICI Americas Inc

The antihypertensive effect may diminish at the end of the dosing interval.

Clinical significance has not been determined in nypertensive patients.

Please see last page of this advertisement for rief summary of prescribing information. 
ZESTRIL* (lisinopril)

INDICATIONS AND USAGE. Zestril is indicated for the treatment of hypertension. It may be used alone as initial therapy or concomitantly with other classes of antihypertensive agents. In using Zestril, consideratio agranulocytosis, particularly in patients with renal impairment or collagen vascular disease, and that available Zestril is Angioedema of the face, extremities, lips, tongue, glottis and/or larynx has been reported in patients treate

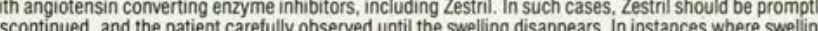
has been confined to the face and lips the condition has generally resolved without treatment, although be fatal. Where there is involvement of the tongue, glottis or larynx, likely to cause airway obstruction, appropriate therapy, eg, subcutaneous epinephrine solution 1:1000 $(0.3 \mathrm{~mL}$ to $0.5 \mathrm{~mL})$ should be prompti administered. (See ADVERSE REACTIONS.) Hypotension: Excessive hypotension was rarely seen in uncom plicated hypertensive patients but is a possible consequence of use with Zestril in salt/volume-depleted persons, such as those treated vigorously with diuretics or patients on dialysis. (See PRECAUTIONS, Drug Interactions insufficiency, excessive hypotension has been observed and may be associated with oliguria and/or progressive azotemia, and rarely with acute renal failure and/or death. Because of the potential fall in blood pressure in these patients, therapy should be started under very close medical supervision. Such patients should be
followed closely for the first two weeks of treatment and whenever the dose of Zestril and/or diuretic is increased. Similar considerations apply to patients with ischemic heart or cerebrovascular disease in whom an excessive the patient should be placed in supine position and, if necessary, receive an intravenous infusion of norma saline. A transient hypotensive response is not a contraindication to further doses which usually can be given without difficulty once the blood pressure has increased after volume expansion. Neutropenia/Agranulocytosis: Another angiotensin converting enzyme inhibitor, captopril, has been shown to cause agranulocytosis and bone marrow depression, rarely in uncomplicated patients but more frequently in patients with renal impairmen to show that Zestril does not cause agranulocytosis at similar rates. Periodic monitoring of white blood cell counts in patients with collagen vascular disease and renal disease shich changes in renal function may be anticipated in susceptible individuals. In patients with severe congestive heart failure whose renal function may depend on the activity of the renin-angiotensin-aldosterone system treatment with angiotensin converting enzyme inhibitors, including Zestril, may be associated with oliguria and/or progressive azotemia and rarely with acute renal failure and/or death. In hypertensive patients with unilateral or bilateral renal artery stenosis, increases in blood urea nitrogen and serum creatinine may occur. reversible upon discontinuation of Zestril and/or diuretic therapy. In such'patients, renal function should be monitored during the first few weeks of therapy. Some hypertensive patients with no apparent pre-existing renal vascular disease have developed increases in blood urea nitrogen and serum creatinine, usually mino and transient, especially when Zestril has been given concomitantly with a diuretic. This is more likely the diuretic may be required. Evaluation of the hypertensive patient should always include assessment of renal function. (See DOSAGE AND ADMINISTRATION.) Hyperkalemia: In clinical trials hyperkalemia (serum potassium greater than $5.7 \mathrm{mEq} / \mathrm{L}$ ) occurred in approximately $2.2 \%$ of hypertensive patients and $4.0 \%$ of

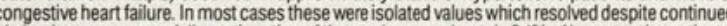
therapy. Hyperkalemia was a cause of discontinuation of therapy in approximately $0.1 \%$ of hypertensive patients. Risk factors for the development of hyperkalemia include renal insufficiency, diabetes melitus, and concomitant use of potassium-sparing diuretics, potassium supplements and/or potassium-containing salt
substitutes, which should be used cautiously, if at all, with Zestril. (See Drug Interactions.) Surgery/Anesthesia: In patients undergoing major surgery or during anesthesia with agents that produce hypotension, Zestril may block angiotensin II formation secondary to compensatory renin release. If hypotension occurs and is con Angioedema: Angioedema, including laryngeal edema, may occur especially following the first dose of Zestril. Patients should be so advised and told to report immediately any signs or symptoms suggesting angioedema (swelling of face, extremities, eyes, lips, tongue, difficulty in swallowing or breathing) and to take no more drug until they have consulted with the prescribing physician. Symptomatic Hypotension: Patients should be cautioned to report lightheadedness especially during the first few days of therapy. If actual syncope occurs, the patient should be told to discontinue the drug until they have consulted with the prescribing physician All patients should be cautioned that excessive perspiration and dehydration may lead to an excessive fal in blood pressure because of reduction in fluid volume. Other causes of volume depletion such as vomiting or diarrhea may also lead to a fall in blood pressure; patients should be advised to consult with their physician. Hyperkalemia: Patients should be told not to use salt substitutes containing potassium without consulting their physician. Neutropenia: Patients should be told to report promptly any indication of infection (eg. sore throat, fever) which may be a sign of neutropenia. NOTE: As with many other drugs, certain advice to patients being treated with Zestril is warranted. This information is intended to aid in the safe and effective use of this medication. It is not a disclosure of all possible adverse or intended effects. Drug Interactions. Hypotension - Patients on Diuretic Therapy: Patients on diuretics and especially those in whom diuretic therapy tension-Patients on Diuretic Therapy: Patients on dice an excessive reduction of blood pressure after initiation
was recently instituted, may occasionally experience an was recently instituted, may occasionally experience an excessive reduction of blood pressure after initiation
of therapy with Zestril. The possibility of hypotensive effects with Zestril can be minimized by either discontinuing of therapy with Zestril. The possibility of hypotensive effects with Zestril can be minimized by either discontinuing
the diuretic or increasing the salt intake prior to initiation of treatment with Zestril. If it is necessary to continue the diuretic or increasing the salt intake prior to initiation of treatment with Zestril. If it is necessary to continue
the diuretic, initiate therapy with Zestril at a dose of $5 \mathrm{mg}$ daily, and provide medical supervision after the the diuretic, initiate therapy with Zestril at a dose of $5 \mathrm{mg}$ daily, and provide medical supervision after the WAitial dose for at least two hours and until blood pressure has stabilized for at least an additional hour. (See Zestril, an additional antihypertensive effect is usually observed. Studies with ACE inhibitors in combination with diuretics indicate that the dose of the ACE inhibitor can be reduced when it is given with a diuretic. (See with diuretics indicate that the dose of the ACE inhibitor can be reduced when it is given with a diuretic. (See
DOSAGE AND ADMINISTRATION.) Indomethacin: In a study in 36 patients with mild to moderate hypertension where the antihypertensive effects of Zestril alone were compared to Zestril given concomitantly with indomethacin, the use of indomethacin was associated with a reduced effect, although the difference between methacin, the use of indomethacin was associated with a reduced effect, although the difference between
the two regimens was not significant. Other Agents: Zestril has been used concomitantly with nitrates and/or the two regimens was not significant. Other Agents: Zestril has been used concomitantly with nitrates and/or
digoxin without evidence of clinically significant adverse interactions. No clinically important pharmacokinetic interactions occurred when Zestril was used concomitantly with propranolol or hydrochlorothiazide. Th presence of food in the stomach does not alter the bioavailability of Zestril. Agents Increasing Serum Potassium Zestril attenuates potassium loss caused by thiazide-type diuretics. Use of Zestril with potassium-sparing diuretics (eg, spironolactone, triamterene or amiloride), potassium supplements, or potassium-containing
salt substitutes may lead to significant increases in serum potassium. Therefore, if concomitant use of these agents is indicated because of demonstrated hypokalemia, they should be used with caution and with frequent monitoring of serum potassium. Carcinogenesis, Mutagenesis, Impairment of Fertility. There was no evidence of a tumorigenic effect when lisinopril was administered for 105 weeks to male and female rats at doses up to $90 \mathrm{mg} / \mathrm{kg} / \mathrm{day}$ (about 56 times* the maximum recommended daily human dose) or when lisinopril was administered for 92 weeks to (male and female) mice at doses up to $135 \mathrm{mg} / \mathrm{kg} /$ day (about 84 times" the
maximum recommended daily human dose). "Based on patient weight of $50 \mathrm{Kg}$. Lisinopril was not mutagenic in the Ames microbial mutagen test with or without metabolic activation. It was also negative in a forward in the Ames microbial mutagen test with or without metabolic activation. It was also negative in a forward
mutation assay using Chinese hamster lung cells. Lisinopril did not produce single strand DNA breaks in an in vitro alkaline elution rat hepatocyte assay. In addition, lisinopril did not produce increases in chromosomal
aberrations in an in vitro test in Chinese hamster ovary cells or in an in vivo study in mouse bone marrow. There were no adverse effects on reproductive performance in male and female rats treated with up to $300 \mathrm{mg} / \mathrm{kg} /$ day of lisinopril. Pregnancy. Pregnancy Category C: Lisinopril was not teratogenic in mice treated on days 6-15 of gestation with up to $1,000 \mathrm{mg} / \mathrm{kg} / \mathrm{day}$ ( 625 times the maximum recommended human dose) There was an increase in fetal resorptions at doses down to $100 \mathrm{mg} / \mathrm{kg}$; at doses of $1,000 \mathrm{mg} / \mathrm{kg}$ this was
prevented by saline supplementation. There was no fetotoxicity or teratogenicity in rats treated with up to prevented by saline supplementation. There was no fetotoxicity or teratogenicity in rats treated with up to
$300 \mathrm{mg} / \mathrm{kg} / \mathrm{day}$ ( $188 \mathrm{~s}$ times the maximum recommended dose) of lisinopril at days 6-17 of gestation. In rats receiving lisinopril from day 15 of gestation through day 21 postpartum, there was an increased incidence in pup deaths on days $2-7$ postpartum and a lower average body weight of pups on day 21 postpartum. The increase in pup deaths and decrease in pup weight did not occur with maternal saline supplementation.
Lisinopril, at doses up to $1 \mathrm{mg} / \mathrm{kg} / \mathrm{day}$, was not teratogenic when given throughout the organogenic period in saline supplemented rabbits. Saline supplementation (physiologic saline in place of tap water) was used dosage level. The rabbit has been shown to be extremely sensitive to angiotensin converting enzyme inhibitors (captopril and enalapril) with maternal and fetotoxic effects apparent at or below the recommended therapeutic dosage levels in man. Fetotoxicity was demonstrated in rabbits by an increased incidence of fetal resorptions dose tested (0.1 mg/kg/day). By whole body autoradiography, radioactivity was found in the placenta following dose tested (0.1 mg/kg/day), By whole body autoradiography, radioactivity was found in the placenta following and well-controlled studies in pregnant women. Zestril should be used during pregnancy only if the potential benefit justifies the potential risk to the fetus. Nursing Mothers: Milk of lactating rats contains radioactivity benefit justifies the potential risk to the fetus. Nursing Mothers: Milk of lactating rats contains radioactivity
following administration of ${ }^{4} \mathrm{C}$ lisinopril. It is not known whether this drug is excreted in human milk.
ZESTRIL" (lisinopril)

Because many drugs are excreted in human milk, caution should be exercised when Zestril is given to a nursi
mother. Pediatric Use: Safety and effectiveness in children have not been established. ADVERSE REACTION Zestril has been found to be generally well tolerated in controlled clinical trials involving 2003 patients a $(5.3 \%)$, fatigue $(3.3 \%)$, diarrhea $(3.2 \%)$, upper respiratory symptoms $(3.0 \%)$, and cough (2.9\%), all of whi were more frequent than in placebo-treated patients. For the most part, adverse experiences were mild a transient in nature. Discontinuation of therapy was required in $6.0 \%$ of patients. In clinical trials, the over frequency of adverse experiences could not be related to total daily dosage within the recommended therapeu with Zestril or Zestril plus hydrochlorothiazide in controlled clinical trials, comparative incidence data a
wition listed in the table below. Percent of Patients in Controlled Studies

\begin{tabular}{|c|c|c|c|}
\hline & $\begin{array}{c}\text { Zestril } \\
(n=2003 \dagger) \\
\text { Incidence } \\
\text { (discontinuation) }\end{array}$ & $\begin{array}{c}\text { Zestril/Hydrochlorothiazide } \\
(\mathrm{n}=644 \text { ) } \\
\text { Incidence } \\
\text { (discontinuation) }\end{array}$ & $\begin{array}{c}\text { Placebo } \\
(n=207) \\
\text { Incidence }\end{array}$ \\
\hline $\begin{array}{l}\text { Dizziness } \\
\text { Headache } \\
\text { Fatigue } \\
\text { Diarrhea } \\
\text { Upper Respiratory Symptoms } \\
\text { Cough } \\
\text { Nausea } \\
\text { Hypotension } \\
\text { Rash } \\
\text { Orthostatic Effects } \\
\text { Asthenia } \\
\text { Chest Pain } \\
\text { Vomiting } \\
\text { Dyspnea } \\
\text { Dyspepsia } \\
\text { Paresthesia } \\
\text { Impotence } \\
\text { Muscle Cramps } \\
\text { Back Pain } \\
\text { Nasal Congestion } \\
\text { Decreased Libido } \\
\text { Vertigo }\end{array}$ & $\begin{array}{l}6.3(0.6) \\
5.3(0.2) \\
3.3(0.2) \\
3.2(0.3) \\
3.0(0.0) \\
2.9(0.4) \\
2.3(0.3) \\
1.8(0.8) \\
1.5(0.4) \\
1.4(0.0) \\
1.3(0.4) \\
1.3(0.1) \\
1.3(0.2) \\
1.1(0.0) \\
1.0(0.0) \\
0.8(0.0) \\
0.7(0.2) \\
0.6(0.0) \\
0.5(0.0) \\
0.3(0.0) \\
0.2(0.1) \\
0.1(0.0)\end{array}$ & $\begin{array}{l}9.0(0.9) \\
4.3(0.5) \\
3.9(0.5) \\
2.6(0.3) \\
4.5(0.0) \\
4.5(0.8) \\
2.5(0.2) \\
1.6(0.5) \\
1.6(0.2) \\
3.4(0.2) \\
2.0(0.2) \\
1.2(0.2) \\
1.4(0.0) \\
0.5(0.2) \\
1.9(0.0) \\
2.0(0.2) \\
1.6(0.3) \\
2.8(0.6) \\
1.1(0.0) \\
1.2(0.0) \\
1.2(0.0) \\
1.1(0.2)\end{array}$ & $\begin{array}{l}1.9 \\
1.9 \\
1.0 \\
2.4 \\
0.0 \\
1.0 \\
2.4 \\
0.5 \\
0.5 \\
1.0 \\
1.0 \\
1.4 \\
0.5 \\
1.4 \\
0.0 \\
0.0 \\
0.0 \\
0.5 \\
1.4 \\
0.0 \\
0.0 \\
0.0\end{array}$ \\
\hline
\end{tabular}

fincludes 420 patien
diuretic therapy.

Clinical adverse experiences occurring in $0.3 \%$ to $1.0 \%$ of patients in the controlled trials and rarer, seriou possibly drug related events reported in uncontrolled studies or marketing experience included: BODY thythm disturbances, tachycardia, peripheral edema, palpitation. DIGESTIVE: Abdominal pain, anorexia, co stipation, flatulence. METABOLISM: Gout. MUSCULOSKELETAL: Joint pain, shoulder pain. NERVOUS SY
TEM/PSYCHIATRIC: Depression, somnolence, insomnia, stroke. RESPIRATORY SYSTEM: Bronchitis, sinusit pharyngeal pain. UROGENITAL: Oliguria, progressive azotemia, acute renal failure. OTHER: Blurred visio pruritus, urinary tract infection, vasculitis of the legs. ANGIOEDEMA: Angioedema has been reported in patien receiving Zestril $(0.1 \%)$. Angioedema associated with laryngeal edema may be fatal. If angioedema of th face, extremities, lips, tongue, glottis and/or larynx occurs, treatment with Zestril should be discontinue and appropriate therapy instituted immediately. (See WARNINGS.) HYPOTENSION: In hypertensive patient hypotension occurred in $1.2 \%$ and syncope occurred in $0.1 \%$ of patients. Hypotension or syncope was cause of discontinuation of therapy in $0.5 \%$ of hypertensive patients. (See WARNINGS.) In patients wit congestive heart failure, hypotension occurred in $5.0 \%$ and syncope occurred in $1.0 \%$ of patients. Thes Test Findings. Serum Electrolytes: Hyperkalemia (See PRECAUTIONS.) Creatinine, Blood Urea Nitroge ren and serum creatinine, reversible upon discontion observed in about $2.0 \%$ of patients with essential hypertension treated with Zestril alone. Increases we more common in patients receiving concomitant diuretics and in patients with renal artery stenosis. (SE approximately $9.1 \%$ of patients with congestive heart failure on concomitant diuretic therapy. Frequent these abnormalities resolved when the dosage of the diuretic was decreased. Hemoglobin and Hematocr Small decreases in hemoglobin and hematocrit (mean decreases of approximately $0.4 \mathrm{~g} \%$ and $1.3 \mathrm{vol} / \mathrm{g}$ thoctively) occurred frequenty in patients treated with Zestril but were rarely of cilinical importance in patien 0 anemia. Other (Causal Relationship Unknown): Rarely. elevations of liver enzymes and/or serum bilirub have occurred. Overall, $2.0 \%$ of patients discontinued therapy due to laboratory adverse experiences, principal The oral L D dosage would be hypotension, for which the usual treatment would be intravenous infusion of normal salir tension not on diuretic therapy, the recommended initial dose is $10 \mathrm{mg}$ once a day. Dosage should be adj according to blood pressure response. The usual dosage range is $20.40 \mathrm{mg}$ per day administered in a sing daily dose. The antihypertensive effect may diminish toward the end of the dosing interval regardless of th pressure just prior, but most commonly with a dose of $10 \mathrm{mg}$ daily. This can be evaluated by measuring blo it is not, an increase in dose should be considered. Doses up to $80 \mathrm{mg}$ have been used but do not appe to give greater effect. If blood pressure is not controlled with Zestril alone, a low dose of a diuretic may b diuretic, it may be possible to reduce the dose of Zestril. Diuretic Treated Patients: In hypertensive patien (ative patien the initial dose of Zestril. The diuretic should be discontinued, if possible, for two or three days before beginnin therapy with Zestril to reduce the likelihood of hypotension. (See WARNINGS.) The dosage of Zestril shou adjusted according to blood pressure response. If the patient's blood pressure is not controlled with Zest: lone, diuretic therapy may be resumed as described above. If the diuretic cannot be discontinued, an initi: cose of $\mathrm{mg}$ should be used under medical supervision for at least two hours and until blood pressure ha administration of Zestril with potassium supplements, potassium salt substitutes, or potassium-sparin diuretics may lead to increases of serum potassiv of Zestril. Pharmacokinetic studies, however indicate that maximum blood levels and area under the plasm concentration time curve (AUC) are doubled in older patients so that dosage adjustments should be mad with particular caution. Dosage Adjustment in Renal Impairment: The usual dose of Zestril (10 mg) $3 \mathrm{mg} / \mathrm{dL}$ ). For patients with creatinine clearance $>10 \mathrm{~mL} / \mathrm{min} \leq 30 \mathrm{~mL} / \mathrm{min}$ (serum creatinine $\geq 3 \mathrm{mg} / \mathrm{dL}$. the first dose is $5 \mathrm{mg}$ once daily. For patients with creatinine clearance $<10 \mathrm{~mL} / \mathrm{min}$ (usually on hemodialysi or to a maximum of $40 \mathrm{mg}$ daily.

\begin{tabular}{|lcc|}
\hline Renal Status & Creatinine-Clearance $\mathrm{mL} / \mathrm{min}$ & Initial Dose mg/day \\
\hline Normal Renal Function to Mild Impairment & $>30$ & 10
\end{tabular}

$\begin{array}{ll}\begin{array}{l}\text { Normal Renal Function to Mild Impairment } \\ \text { Moderate to Severe Impairment }\end{array} & \geq 30 \\ \text { Dialysis Patients } & \geq 10 \leq 30\end{array}$

tDosage or dosing interval should be adjusted depending on the blood pressure response. Rev E 12/8 Distributed by: Stuart Pharmaceuticals, Division of ICI Americas Inc, Wilmington, DE 19897.

REFERENCES: 1. Zestrile (lisinopril) full prescribing information issued December 1987. 2. Ajayi AA, Campbell BC Kelman AW, et al: Pharmacodynamics and population pharmacokinetics of enalapril and lisinopril. Int J Clin Pharmac

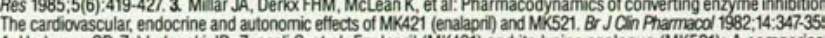
4. Hodsman GP, Zabludowski JR, Zoccali C, et al: Enalapril (MK421) and its lysine analogue (MK521): A compariso of acute and chronic effects on blood pressure, renin-angiotensin system and sodium excretion in normal man. Br JCK
Pharmacol 1984;17:233-241. 5. Physicians' Desk Reference, ed 42. Oradell, NJ, Medical Economics Co. 1988. Vasotec enalapril maleate, MSO), pp 1406-1408. 6. Physicians' Desk Reference, ed 42. Oradell, NJ, Medical Economics C
1988. Capoten (MK-521): Disposition in man. Br J Clin Pharmacol ig82; 14:357-362. 8. Mojaverian P. Rocci ML Jr. Vlasses PH, et Effect of food on the bioavailability of lisinopril, a nonsulfhydryl angiotensin-converting enzyme inhibitor. J Pharm S
$1986 ; 75: 395-397$. 